\title{
Career prospects for young people in public high schools in Brazil: transgression or reproduction of social conditions?
}

\author{
HELIANI BERLATO ${ }^{1}$ \\ LUCIANO MENDES ${ }^{1}$ \\ DANILO ANDRETTA ${ }^{1}$
}

1 Universidade de São Paulo (USP) / Escola Superior de Agricultura “Luiz de QueIRoz", Programa de Pós-graduação em ADMINISTRAÇÃO, PIRACICABA - SP, BRAZIL

\begin{abstract}
This article aims to analyze young people's career prospects in public high schools in a city in the state of São Paulo, considering social, family, educational, and cultural aspects. Career was discussed from two perspectives: career success and career indecision. The article contributes to career discussions by bringing the theory of French sociologist Pierre Bourdieu, who investigates the limits of the educational system to contribute to individuals' careers. Quantitative research was carried out with 3,287 high school students from public schools in a city in the state of São Paulo. After collection, the data were analyzed using exploratory factor analysis and cluster analysis. Six clusters of high school youths from the public schools were found. The results showed that the differences that allowed gathering these clusters were linked to family and social class reproductions more than to the role played by the school.
\end{abstract}

Keywords: Bourdieu. Career. Social class. Young people.

Perspectivas de carreira de jovens do ensino médio de escolas públicas: transgressão ou reprodução das condições sociais?

\section{Resumo}

O objetivo deste artigo foi analisar as perspectivas de carreiras dos jovens do ensino médio público de uma cidade do interior de São Paulo, no que tange aos aspectos sociais, familiares, educacionais e culturais. Para tanto, discutiu-se a carreira a partir de duas perspectivas: o sucesso e as indecisões inerentes a ela. Uma contribuição do artigo foi trazer para a discussão de carreira a teoria do sociólogo francês Pierre Bourdieu, que discute os limites do sistema educacional para a contribuição na carreira dos indivíduos. Realizou-se uma pesquisa quantitativa com 3.287 alunos do ensino médio de escolas públicas em uma cidade no interior do Estado de São Paulo. Após a coleta, os dados foram analisados a partir da Análise Fatorial Exploratória e da Análise de Agrupamentos. Foram encontrados seis agrupamentos de jovens do ensino médio das escolas públicas pesquisadas. Em termos de resultados, as diferenças que permitiram a constatação desses grupos foram mais vinculadas às reproduções familiares e das classes sociais do que necessariamente ao papel exercido pela escola.

Palavras-chave: Bourdieu. Carreira. Classe social. Jovens.

\section{Perspectivas de carrera para los jóvenes de la escuela secundaria pública en Brasil: ¿transgresión o reproducción de las condiciones sociales?}

\section{Resumen}

El objetivo de este artículo fue analizar las perspectivas de carrera de los jóvenes de la escuela secundaria pública en una ciudad del interior de São Paulo, con respecto a los aspectos sociales, familiares, educativos y culturales. Para ello, la carrera se discutió desde dos perspectivas: el éxito y la indecisión. inherentes a ella Una contribución del artículo fue llevar la teoría del sociólogo francés Pierre Bourdieu a la discusión sobre la carrera, que analiza los límites del sistema educativo para la contribución a la carrera de las personas. Se realizó una investigación cuantitativa con 3.287 estudiantes de secundaria de escuelas públicas en una ciudad del estado de São Paulo. Después de la recolección, los datos se analizaron mediante el análisis factorial exploratorio y el análisis de conglomerados. Se encontraron seis grupos diferentes de jóvenes de secundaria de las escuelas públicas encuestadas. En términos de resultados, las diferencias que permitieron la constatación de estos grupos estaban más vinculadas a las reproducciones familiares y de clase social que necesariamente al papel desempeñado por la escuela.

Palabras clave: Bourdieu. Carrera. Clase social. Jóvenes. 


\section{INTRODUCTION}

The interdisciplinary character attributed to career studies justifies the various perspectives that career theory presents (Hall, 2002; ARTHUR, 1994). The participation of the various study areas is expressive and important for constructing what is understood as a career according to contemporary viewpoints (HARRINGTON and HALL,2007). Three career perspectives have been highlighted in recent years: a borderless career, a smart career and a post-corporate career. The first perspective treats the career as an individual and non-organizational process, involving an individual who is active in determining their own career path and not passive in their choices (ARTHUR, 1994). The second perspective focuses on self-knowledge and self-awareness, in the sense of a constant search by the individual for the knowledge necessary for developing their activities (DEFILLIPI and ARTHUR, 1994). The final perspective observes the fluidity and flexibility of work relationships, but also establishes the career from an individual perspective that focuses on the changes the individual must undergo to adapt to the changing world (PEIPERL and BARUCH, 1997).

A career can be conceptualized as a sequence of work experiences over time (ARTHUR, HALL and LAWRENCE, 1989), which shows two fundamental aspects that lead to this understanding. The first is a subjective career that is linked to the understanding the individual has about their own career and about what they are becoming. The second is an objective career, linked to social position, promotion and status, which serves to measure the professional trajectory of the individual. It is, therefore, clear that it is impossible to separate the subjective career from the objective career, which shows that one of the important elements is precisely the way in which social position, promotion and status are idealized and achieved. This makes career success an important discussion in the field of career theories (ARTHUR, KHAPOVA and WILDEROM, 2005).

With regard to career success, the influences on the choice of career are both subjective (choice, motivation, satisfaction) and objective (an attractive salary, the number of promotions, social position). Career success can be defined as achieving desirable work-related results at any time in an individual's experience. The individual sees career success as something desirable (subjective) and something capable of generating prosperity (objective) through comparisons with other individuals. These subjective and objective conditions in career success are so intertwined that the existence of one is directly related to the other. This is because subjective career success is conceptualized as the individual's internal apprehension of those external dimensions (income, safety at work, status, progression, access to teaching) that are important to them. Objective success in the career is conceptualized as an external dimension (occupation, family situation, income, level of employment) that defines the situation of an individual's career (ARTHUR, KHAPOVA and WILDEROM, 2005).

That said, it is clear that the career, despite being seen as the work sequence of an individual, depends on the positive (or not) view that the individual has about his/her professional trajectory, and also on the social conditions and possibilities of that career. These discussions have marginalized the barriers and difficulties faced by individuals in their careers, such as unemployment situations (THOMPSON, DAHLING, CHIN et al., 2017), changes in professional performance, age (NEWMAN, 1995) and limited employment and income opportunities (SUTIN, COSTA JUNIOR, MIECH et al., 2009). In addition, access to an education system (high school and higher education) that is capable of leveraging careers objectively, and the distinctions between social classes (status, social position), can be factors that limit career success being achieved. This is because, while revealing a scenario of career prospects, career success conditions the desires of individuals to fit their social status, which is guided by this objective aspect (CONNOLLY and HEALY, 2004).

Given this objective influence, which acts directly on the way young people conceive of their career prospects, some career studies have been developed with those who are not yet in the labor market (ROGNSTAD, AASLAND and GRANUM, 2004), or who are still at the beginning of their professional activities, in order to observe possible configurations within these perspectives (AKKERMANS, BRENNINKMEIJER, SCHAUCHAUI et al., 2015). Such studies have focused on topics such as "career prospects" (CLARK, JOUBERT and MAUREL, 2017), "career choices" (ZELLWEGER, SIEGER and HALTER, 2011) and "career indecision" (DENAULT, RATELLE, DUCHESNE et al., 2019). Most studies are conducted with students, showing that the education system (elementary, middle and higher) is of central importance to the scope and development of the career (WRIGHT, JENKINS-GUARNIERI and MURDOCK, 2008). 
One of the few studies developed in this line is that by Gale and Parker (2015). These authors assessed that with regard to the career choices of lower-class high school students in Australia, their aspirations were to enter higher education. The authors conclude that although there is a level of agency in these lower-class students, which occurs more in their social relationships than in the historical determinants, there are still structural limitations that prevent them from having access to higher education and success in their career choices. For lower class young people who are able to enter higher education in developed countries, the reality is also not promising. In Lehmann's (2012) study of young, lower-class Canadian university students (working class), it is evident how difficult they find it to adapt to the university habitus. That is because Canada's higher education system is dominated by middle-class young people, which requires those in the lower class to constantly negotiate. Lehmann (2012) concludes that this negotiation, for example, allows lower-class young people to adapt better when they have clear career choices. But even if some manage to adapt to the university habitus, the chances of career success are still limited.

It was based on these findings, that there is a close relationship between career and the education system, that career development is different for young people from different social classes, and that there are possible habitus in the education system (elementary, middle and higher), that this article was constituted. Like the work by Gale and Parker (2015), the research conducted in this article involved high school students from public schools in a city in the interior of São Paulo, the objective being to analyze their career prospects based on social, family, educational and cultural aspects.

The following topics deal initially with Bourdieu's contributions to career studies. Emphasis will be placed on Bourdieu's theory, not on an in-depth exploration of career theories. Next, the methodological aspects of the research will be presented. The results of the research will then be presented and analyzed from the viewpoint of Bourdieu's theory and habitus. This will be followed by the final considerations.

\section{Bourdieu's contributions to career studies}

To begin this approximation to the career perspectives of Bourdieu's Sociology of Education, it is important initially to understand the context in which this author's theory was developed. Bourdieu began formulating his Sociology of Education in the 1960s and it led to a revolution in the way education and the education system were seen (NOGUEIRA and NOGUEIRA, 2002). Until then educational ideology observed the system as a meritocratic and republican way of understanding teaching. Schools allowed equal access for all, thereby minimizing those actions that generate any type of discrimination (VALLE, 2013). This educational ideology enabled a rapid expansion of education systems (initially they were elementary and high school systems). In the 1960s, France witnessed the expansion and massification of the "secondary" school (high school in Brazil,), which failed to minimize social inequality. Bourdieu (1986) observes that this happened because the school became a system for reproducing social conditions, and never a system that was capable of expanding school content to reduce social inequalities. This is because the school ended up reproducing elements that have social class values, and never the values of the education system. Bourdieu and Paresson (1975) exemplify this by pointing out that the teacher considers the adjective "school" - as opposed to "talent" - to be pejorative, because the latter is linked to inherited cultural capital.

In relation to cultural capital, Bourdieu (1986) evaluates the role of the family and social classes, which allow elements to be: interiorized (ways of seeing the world and tasting wine, for example); objectified (owning a library or works of arts); and institutionalized (obtaining a diploma that is recognized by the State). Riutort (2008) considers that this reproduction within the school creates a process of "acculturation" of the popular classes, to the extent that these classes do not have legitimate cultural capital. This reproduction of the ruling classes in the education system is so strong that Bourdieu (1986) points out that if the son of a worker attended school and then became a worker it was because he did not have the credentials to be a "good student".

This form of reproduction is more understandable from Bourdieu's discussions (1989) on the concept of habitus. Bourdieu (1989) understands habitus to be a system of individual, socially constituted schemes of structured (in-social) and structuring (in-mind) dispositions, acquired from practical experience. Bourdieu's habitus theory enables the individual and society to be linked and reconciled, thus providing evidence that knowledge is initially obtained in the family environment (familiarity), in the social environment (objectivist) and in the practical environment (praxiological). The latter is produced "in the dialectical relations between structures and the structured dispositions in which they are updated and tend to reproduce themselves" (BOURDIEU, 1983, p. 47). Habitus is a socialized subjectivity (BOURDIEU, 1992). 
This brief explanation of the concept of habitus shows how the school system reproduces social inequalities and generates a level of meritocracy for the ruling classes. Thus, Bourdieu and Paresson (1975) work on analyzing the school system, and economic and social capital in addition to inherited cultural capital. Based on the success and failure experienced by the individual, by family members and by the close social group, what can or cannot be achieved starts being formed, including in the education system itself. Bourdieu and Paresson (1975) observe that for the economically upper classes educational investments are not as intense as they are for the middle class, as the latter seeks to raise their social standing by way of school certificates. Another problem that Bourdieu and Paresson (1975) point out is linked to the massification of education, which tends to devalue school diplomas and stimulate the attributes of the ruling classes that transcend those to which the popular classes have access.

The theory of capital is central to the analysis of the school system developed by Bourdieu and Paresson (1975), because it enables an understanding of the inequalities and class differences involved in gaining access to this system. Economic capital integrates economic and production goods (money, income, goods, labor). Social capital is linked to primary (family) and secondary social networks (groups and social classes), thus constituting the various habitus. Cultural capital is linked in its institutionalized form to academic qualifications and the importance of these titles in the social positions of agents (BOURDIEU, 1986).

Bourdieu and Paresson (1975) note three possible strategies and provisions related to the education system, which are linked to the economic and time investments made by the popular classes, the middle classes and the elites. The popular classes would invest less in education systems for the reduced capital (economic and cultural), mainly because they believe that their chances of success are limited. Because the returns on investments in education are long-term, the popular classes would tend to avoid this type of spending. The middle classes would tend to invest more heavily in education, thus aiming for better social positions by way of academic success. This social group would tend to see the future as drawing closer to the social conditions experienced by the elites; it also leads to this group's increasing differentiation from the popular classes. Finally, the elites would invest less time in formal education because they have greater cultural capital, this being one of the demands of the school system that favors the most "talented" students. Here, Bourdieu and Paresson (1975) distinguish the elites who are rich in cultural capital from those who are rich in economic capital. The wealthiest elites in cultural capital invest in the education system in order to pursue longer and more prestigious careers. The wealthiest elites in economic capital invest only to obtain diplomas that legitimize their social position.

In discussing the context of public education in Brazil, these forms of class reproduction are evident (VARGAS, 2009).In the study conducted by Bonamino, Alves and Franco (2010), which used quantitative data from the International Student Evaluation Program in 2000 in Brazil, it is obvious that, indeed, the various types of capital (social, cultural and economic) have an influence on the school performance of students. Based on the literature, the authors created five conglomerates that took into account, for example, the possession of (economic) goods, the family's (social) educational resources, and the mother's (cultural) level of education. Bonamino, Alves and Franco (2010) conclude that ownership of these types of capital enables students to perform better academically, showing that this form of class reproduction is also observed in the Brazilian education system.

If class reproduction exists, then career prospects, career choices, or career indecision also follow this reproduction logic. It is at this point that it is clear that, from the viewpoint of Bourdieu and Paresson (1975), and with regard to career prospects, choices or indecision, the lower classes (popular or working class) do not have the privilege of being able to manage their careers, because they have little social, cultural and economic capital. Moreover, if the education system, which is central to career development, reproduces this distinction between the classes, then the development possibilities of the lower classes are limited. It is along these lines that Bourdieu and Paresson (1975) point out that, since the education system reproduces the social, cultural and economic capital of the upper classes, or the elites, the lower classes are obviously limited when it comes to achieving positions and a higher status in the labor market. Given this finding, it is clear that any discourse about borderless careers, smart careers or corporate careers is more closely associated with the upper classes than with enabling the lower classes to have access to better positions in the labor market. 


\section{METHODOLOGICAL PATH}

The study's methodological path is affiliated with Bourdieu's reflexive sociology (2002). Such a way of doing science is understood as rational activity, but the main purpose is to draw on common sense, which leads to reflections that go beyond those that have already been reified in the social context. For this reason, this study is a reflection on the education system as a reproducer of class. Likewise, ideas related to career also follow this same reproduction, being observed much more in the upper classes than in the lower classes.

Field and habitus are central to the sociological method in Bourdieu (2002). This is because the field generates a relational space, in which agents and institutions produce and reproduce. The field establishes a direct relationship between society and the individual that allow, in a relatively autonomous way, for the existence of its own laws that structure the behavior of agents. It is in the field that the various types of capital (social, cultural and economic) are used, creating distinctions and power relations. The durable provisions that maintain these distinctions between agents will occur as a result of the integration of agents in the various fields. It is this process of incorporation and the knowledge acquired in the field that Bourdieu (2002) calls habitus.

To understand field and habitus, Bourdieu used several research methods, which ranged from ethnography to statistical analyses of quantitative data. As Thiry-Cherques reminds us (2006, p. 45), analysis of habitus (positions and incorporations) and field (logic and structure) is revealed by explaining social life, not by way of interviews, but with "statistical analyses of correlations in the unveiling of deep structures". Thiry-Cherques (2006) points out that the attempt to understand social and professional hierarchy from questions that start with "in your opinion..." would be limited by to doxa (common sense). Statistical analyses help minimize the effects of doxa, and provide evidence of hierarchies, distinctions and class reproduction.

Noting the importance of statistical analysis for understanding the distinctions between social classes and hierarchies in fields, quantitativeresearch was conducted that was developed using a closed questionnaire with ten questions related initially to sociodemographic characteristics, and in the second stage with 49 assertions on a 7-point Likert scale, which ranged from "totally disagree" to "totally agree". As the theory of capital is a central aspect of the analysis of Bourdieu and Paresson (1975) and also reveals habitus, the questionnaire was designed on the basis of statements that represent the existence of the economic, social and cultural capital of the students participating in the research.

The research involved the participation of 15 state public schools of a city in the interior of São Paulo, chosen on the basis of a geographic criterion (the neighborhoods where the schools are located) and the fact that the schools had both the time required and the space available for applying the questionnaire. The research was endorsed by and received contributions from the Municipal Department of Education, and was approved by the Ethics Committee. For this reason, the names of the schools and students have been omitted as this information is not relevant for the purposes of this research. Information was collected from full-time students (4 schools), night-time students (4 schools) and morning-time students (11 schools), with a total of 82 classrooms being visited.

A total of 3,303 questionnaires were applied, of which 3,287 were considered valid for the purposes of the research. Compared to the total number of students enrolled in state public schools in the municipality that was surveyed - approximately 10,024 students the sample consists of about $33 \%$ of the number of students in public schools during the period in which the research was conducted. Of the respondents, $24 \%$ reported they were working and $76 \%$ declared they did not work.

To analyze the sociodemographic part of the questionnaire, we used the proportion (percentage) calculation for each analyzed variable. For the part relating to the concordance scale (Likert), multivariate techniques were used for the analysis, including Exploratory Factor Analysis and Cluster Analysis.

Exploratory Factor Analysis was used to reduce the number of scale variables to the smaller number of factors that represented the original structure. Refinement of the scale led to some indicators being excluded, and six factors being extracted. A KMO of 0.798 was obtained, the null hypothesis of the Bartlett test was rejected and there was a $47.83 \%$ explained variance, which suggests a good fit of the factorial model. 
The factors that were obtained and used as the basis of the cluster analysis a posteriori were the following: Factor 1 - Financial gain and status as a career determinant; Factor 2 - Presence of the family and work as a priority; Factor 3 - Study is important; Factor 4-Great uncertainty about the professional choice; Factor 5 - Work is a current necessity; and Factor 6 - Public education discriminates against me. Hair, Sant'Anna and Gouvêa (2009) indicate that the Alpha coefficient is an estimate that is often applied, but that it may underestimate reliability. Considering the relevance of the factors for understanding the phenomenon, therefore, Factor 6 was maintained, as it reveals an important condition about how public high school education is seen in Brazil. Table 1 shows the factors that were found in factor analysis, the variables related to the factors, the factor load of each of the variables, Cronbach's Alpha for each of the factors, and the theoretical basis for each of the factors. As the variables were constructed from the theory of capital, factor analysis and groupings revealed the predominance of one of the types of capital (either economic, social and cultural) for each of the factors found.

Table 1

Adjustment indicators of exploratory factor analysis and the economic, social and cultural capital

\begin{tabular}{|c|c|c|c|c|}
\hline Factors & Variables & $\begin{array}{l}\text { Factor } \\
\text { loading }\end{array}$ & $\begin{array}{l}\text { Cronbach's } \\
\text { Alpha }\end{array}$ & $\begin{array}{l}\text { Theoretical basis: } \\
\text { Bourdieu's capital theory }\end{array}$ \\
\hline \multirow{6}{*}{$\begin{array}{l}\text { Financial gain and } \\
\text { status as a career } \\
\text { determinant }\end{array}$} & The desire to earn a high salary influences my career choice & 0.73 & \multirow{6}{*}{0.73} & \multirow{6}{*}{ Economic Capital } \\
\hline & I want a profession that allows me to buy everything I want & 0.67 & & \\
\hline & Making money is what makes me pursue a career & 0.67 & & \\
\hline & If I have a career, I'm sure I'Il make more money & 0.61 & & \\
\hline & To have a career is to succeed & 0.58 & & \\
\hline & My happiness lies in the amount of money I'm going to make & 0.55 & & \\
\hline \multirow{8}{*}{$\begin{array}{l}\text { Presence of the } \\
\text { family and work } \\
\text { as a priority }\end{array}$} & I prefer to start my family before I study & 0.66 & \multirow{8}{*}{0.63} & \multirow{8}{*}{ Social capital } \\
\hline & $\begin{array}{l}\text { My professional choice is linked to my parents' professional } \\
\text { choice }\end{array}$ & 0.65 & & \\
\hline & I'm thinking of stopping studying to work & 0.61 & & \\
\hline & To work, I don't need to study & 0.48 & & \\
\hline & I'd rather take a technical course than a college course & 0.46 & & \\
\hline & I believe my friends can influence my professional choice & 0.44 & & \\
\hline & I can't imagine going to a public college & 0.37 & & \\
\hline & $\begin{array}{l}\text { I give up choosing the career I want so I don't want to demand } \\
\text { from my parents what they can't give }\end{array}$ & 0.31 & & \\
\hline \multirow{4}{*}{ Study is important } & $\begin{array}{l}\text { My teachers give me the knowledge I'm going to use for the } \\
\text { rest of my life }\end{array}$ & 0.69 & \multirow{4}{*}{0.61} & \multirow{4}{*}{ Cultural capital } \\
\hline & To have a career, you need to study hard & 0.64 & & \\
\hline & I really like studying & 0.63 & & \\
\hline & If I'm a good student, I'm sure I'll have a good career. & 0.60 & & \\
\hline \multirow{3}{*}{$\begin{array}{l}\text { Great uncertainty } \\
\text { about professional } \\
\text { choice }\end{array}$} & I'm undecided on the choice of career I intend to pursue & 0.77 & \multirow{3}{*}{0.61} & \multirow{3}{*}{ Social capital } \\
\hline & I'm afraid to pick a career and not like it & 0.66 & & \\
\hline & $\begin{array}{l}\text { I feel pressured into choosing what I'm going to do when I } \\
\text { finish high school }\end{array}$ & 0.60 & & \\
\hline \multirow{2}{*}{$\begin{array}{l}\text { Work is a current } \\
\text { necessity }\end{array}$} & Nowadays, I need to work & 0.79 & \multirow{2}{*}{0.60} & \multirow{2}{*}{ Economic capital } \\
\hline & I need to work as soon as I finish high school. & 0.76 & & \\
\hline \multirow{2}{*}{$\begin{array}{l}\text { Public education } \\
\text { discriminates } \\
\text { against me }\end{array}$} & It is very difficult to pass the entrance exam for a public college & 0.72 & \multirow[b]{2}{*}{0.35} & \multirow[b]{2}{*}{ Cultural capital } \\
\hline & I feel discriminated against for studying in a public school & 0.70 & & \\
\hline
\end{tabular}

Source: Elaborated by the authors. 
In view of the dimensions obtained and by calculating the arithmetic mean of the questions relating to each factor obtained by factor analysis, cluster analysis was carried out using a hierarchical method, quadratic Euclidean distance, standardization by Z score, and the Ward algorithm for preparing the groups. Following analysis of the grouped data, the groups were labelled: the Decided (13.4\%); the Guided (12.3\%); the Insecure (35.2\%); the Stagnant (19.16\%); the Undecided (10.1\%); and the Pessimistic (9.7\%).

\section{RESULTS AND DISCUSSION}

Having presented the methodological path, the intention in this topic is to examine the characteristics of each of the six groups. This will enable an analysis of the statistical results to transcend any descriptive aspects and provide an understanding of the various types of capital (economic, social and cultural) and of the social class reproduction processes.

\section{The Decided (13.4\%)}

Of all the groups, this was the one that had the lowest degree of uncertainty regarding their professional choice (Factor 4 - Social capital), and the one that least associates financial gain and status (Factor 1 - Economic capital) with the notion of career. With regard to questions about the importance of studying (Factor 3 -Cultural capital) and the current need for work (Factor 5 - Economic capital), this group had significant results. It obtained the highest score of all the groups for Factor 3 and the second highest score for Factor 4. With regard to the presence of family and work as a priority (Factor 2 - Social capital), the group obtained the second lowest score, which was the same as for the idea that public education is discriminatory (Factor 6 - Cultural capital). Analysis of the socioeconomic variables shows that the majority of those in this group are females (63.3\%), the predominant family income is up to $\mathrm{R} \$ 2,640.00$ (61.75\%), and $26.3 \%$ of them are already working.

Reproduction of class and family is evident in this Decided group. The profile is of young people who are extremely determined about which way to go in order to secure employment after leaving high school. They would have no problem going into higher education as long as they could reconcile this with working. Members of this group would, therefore continue studying if they were able to reconcile this with employment, because they are willing to work. The search for work is not restricted to more qualified employment that will allow them to earn more; the idea that drives them is that they need to pursue paid activity. The prospect of a career, or of career success in the sense of aiming for better working conditions and a better life, is not something these young people have set their sights on. They have decided to pursue paid activity, but not necessarily to rise to high positions or achieve social status. This group reproduces the family context, because it is composed of the children of salaried workers, who have had low levels of education.

\section{The Guided (12.3\%)}

Of all the groups, this was the one that had the lowest score with regard to the current need to work (Factor 5 - Economic capital), the discrimination of public education (Factor 6 - Cultural capital), and the presence of the family and the prioritization of work to the detriment of studies (Factor 2 -Social capital). Regarding the issue of financial gain and career-related status (Factor 1 - Economic capital) and the uncertainty of professional choice (Factor 4-Share capital), this group had the second lowest result. With regard to the importance of studying (Factor 3-Cultural capital), this group had the second highest score. The only difference between the previous group (the Decided) and this group is that the former prioritizes studying a lot, but needs to work, whereas this group prioritizes studying, but does not need to work. In analyzing income, the percentage of students with a family income greater than $\mathrm{R} \$ 4,400.00$ is higher for this group (10.6\%) than for the previous group (8.4\%), which could explain the fact that those in the second group y do not need to work, unlike those in the first group. The majority of this group is also female $(56.8 \%)$ and $17 \%$ of them already work.

Despite corresponding to only $12 \%$ of the sample, this group has a positive view of higher education. It is a group made up mostly of women who are looking to break away from their social condition by way of education. This is because the 
experiences of success and failure within the family and the experiences of their close peers encourage the members of this group to look for better living conditions. Most have parents who finished their higher education. This provides them with the guidance they need on what to look for in terms of improving their social condition, but even so, career and career success prospects are limited to education as a legitimate springboard to better social conditions. Despite the guidance they receive, however, this group continues reproducing the social class to which it belongs. As these young people want to go into higher education, they do not care about the discrimination in public schools.

\section{The Insecure $(35.2 \%)$}

The answers in several factors in this group were intermediate (Factor 1 - Economic capital; Factor 2 - Social capital; and Factor 6-Cultural capital). What drew most attention was what they said in response to the questions about the importance of studying (Factor 3 - Cultural capital) and the current need for work (Factor 5 - Economic capital), which tended to give higher scores. There was also their intermediate (neutral) inclination in response to the question about the uncertainty of professional choice (Factor 4 -Social capital). With regard to demographic characteristics, the majority of this group is male (52.3\%), the monthly family income is mostly in the range up to $\mathrm{R} \$ 2,640.00$ (65.47\% - the highest proportion of all groups in this income range), and $22.99 \%$ already undertake some type of paid activity.

This group corresponds to $35 \%$ of the total sample (the largest group), because the social context of their lives places them in this insecure condition. They are young people who need money, but would like to be able to choose a vocational profession, and not out of financial necessity. The dilemma they face is choosing between survival and happiness. Their career prospects are tied to the objective aspects that a career can provide them with, such as salary and promotion, but this group does not intend attaining such positions through education. They need to raise financial resources to support the family. Their parents, generally, do not have a higher education qualification. The financial and social difficulties experienced by the family are manifested by the fact that their need to seek financial gains is more important than securing a vocational profession.

\section{The Stagnant (19.2\%)}

Of all the groups, this was the one that had the lowest score with regard to the importance of studying (Factor 3-Cultural capital). Their results were low for uncertainty (Factor 4 - Social capital), the presence of the family and prioritizing work to the detriment of their studies (Factor 2 - Social capital), and public education as a discriminatory factor (Factor 6 - Cultural capital). The results were intermediate (neutral) for their current need to work (Factor 5 - Economic capital), financial gain and career-related status (Factor 1 - Economic capital). With regard to the sociodemographic variables, the majority of this group is male (63.2\%), their income is also concentrated in the range up to $\mathrm{R} \$ 2,640.00$, and $26.51 \%$ already have some type of paid activity (the highest proportion of all the groups).

This was the group that most reproduced the family condition, and this is why it was labelled The Stagnant group. These students do not view education as a way to take them out of the social condition in which they live. They do not have promising career prospects and they are not aiming to receive high financial rewards in their profession. Members of this group find it very difficult to leave the social condition in which they already live. They have very little cultural capital and low economic capital, and they are firmly attached to the social capital of their family's class. This is the second largest group in the sample, with about $19 \%$ of the respondents, which shows the difficulty Brazilian public schools have when it comes to creating better career prospects.

\section{The Undecided (10.1\%)}

Of all the groups, this was the one that had the highest score in relation to the uncertainty of the choice of profession (Factor 4 - Social capital), the issue of financial remuneration and status as determinants of career (Factor 1 - Economic capital), the presence of the family and prioritizing work to the detriment of studies (Factor 2 -Social capital), and the current need for employment (Factor 5 - Economic capital). With significant results for Factors 1, 4 and 5, and despite having the highest score, the results of this group tended towards the discordant portion of the Factor 2 scale - Social capital. The students in this group also showed that they considered study to be important (Factor 4 - Social capital), but this was the third lowest score for 
this item compared to the other groups, besides also having an intermediate score (neutral) for the issue of discrimination in public education (Factor 6 - Cultural capital). With regard to the sociodemographic characteristics of this group, most were males (59.2\%), the predominant income range is up to $R \$ 2,640.00$ (56.88\%), and $24.02 \%$ are already working.

Based on these findings, the uncertainty with regard to the career choices of this group is very high. As their current need for work is great, this uncertainty may arise from the anxiety they feel at having to start work early; in other words it is as if the pressure to choose were higher. This situation is also reflected in the fact that this group is very concerned about the issue of financial remuneration and status related to their career development.

This group reflects the considerations of Bourdieu and Paresson (1975) well, because financial gain is more important than the choice of a promising career. The aim is to finish high school and enter the market without necessarily knowing for sure which profession to follow or which employment to seek. They give the impression that any employment is ideal. This again shows that education has a marginal role to play in terms of escaping one's social condition. The concern with education will only be important after entering the labor market, and more as a complement to the work already being done (technical course) than as career progress (higher education).

\section{The Pessimists (9.8\%)}

Of all the groups, this had the highest score for the issue of discrimination in public education (Factor 6-Cultural capital). With regard to the other dimensions, no other value tended to the extreme. The question of the importance of studying (Factor 3Cultural capital) obtained a high result, but had the second lowest score among the groups for this particular dimension. The current need to work (Factor 5 - Economic capital) and uncertainty about the choice of profession (Factor 4 -Social capital) had intermediate (neutral) values. A similar situation is observed in the case of Factor 4 (Social capital), in which despite having an intermediate (neutral) score, it was the second highest of all the groups. Socio-demographically, most of this group are females (61.4\%) with a predominant income range up to $R \$ 1,640.00(56.49 \%)$. It is, however, the group that obtained the highest score for the range of income over $\mathrm{R} \$ 4,401.00$ (12.99\%). Of these students, $25.39 \%$ are already in paid activity.

What can be inferred from this scenario is that these students consider studying to be important, but not as important as those in the other groups. They do not need to work urgently (the third lowest score among groups), but they suffer from a certain degree of uncertainty. They believe that a public high school education makes it very difficult for them to get into a public college, and this has discouraged them from pursuing a career that requires a college degree. This fact is linked to the massification of education, which tends to lead to a devaluation of high school diplomas. But it is not only this: massification also tends to devalue public education itself as being capable of leading to a better social condition. This group also includes individuals from the middle classes. This is perhaps why it has no belief in public education. This also explains the fact that these students do not have to decide on a career in the short term. This is the smallest group in the sample, and is an exception in public education in the municipality surveyed.

\section{A comparison of the sociodemographic variables and groups}

In order to unite the two parts of the questionnaire, comparisons were made between the sociodemographic variables and the groups. To analyze the results better and in order for there to be no bias related to the disproportion between the number of students in each group, we opted for the Chi-square standardization $\left(\chi^{2}\right)$ of all data.

With regard to the monthly income of the students' families, these are highest (income between $R \$ 4,401.00$ and $R \$ 13,200.00$ ) in the Guided and Pessimists groups. Family incomes are median in the Decided and Undecided groups in relation to higher family incomes, but the lowest in the survey (income between $R \$ 2,641.00$ and $R \$ 4,400.00$ ). Family incomes are the lowest (less than $\mathrm{R} \$ 880.00$ ) in the Insecure and Stagnant groups.

Here we see evidence of some of the factors in Bourdieu's theory. The first piece of evidence refers to economic capital. Groups with greater purchasing power either receive some kind of family guidance, or are pessimistic about public high schools, as they do not allow them to achieve better social positions. The second piece of evidence refers to social capital. With parents who are employed in better jobs, their guidance with regard to the future results in better social capital. 
This situation corroborates the parents' level of education. If both the father and mother had had the lowest level of education (did not finish elementary school), then it was likely that the students were in the Insecure group, but if both parents had had a higher level of education (graduated from higher education), then it was likely that the students were in the Guided group.

With regard to the parents' profession, in the Decided group the working father was the predominant producer of goods and services, while the mother was in the Others category (deceased, estranged, retired, pensioner, missing, or someone the children do not know). In the Guided group, the father works in the administrative services area and the mother is a mid-level technician. In the Insecure group, the father is a worker producing goods and services, while the mother is unemployed. In the Stagnant group, the father is a businessman or a tradesman, and the mother works in an undefined occupation. In the Undecided group, the father is unemployed and the mother is the head of the family, while in the Pessimists group, both (father and mother) are professionals in the sciences and/or arts.

This correlation between sociodemographic variables and groups is evidence of the condition described by Bourdieu and Paresson (1975) of the reproduction of the family and social classes falling within the scope of public education. Career prospects and future visions of career success are limited for all groups. Education is not a fundamental factor of change in the social condition; capital (economic, social and cultural) is inherited from the family. Cultural capital is only valid when observed in the family or in the reference group. Thus the realities of the groups, far from being completely different for each of them, are very close, with little room for maneuver. Perhaps that is why Bourdieu (1986) preferred the word "agent" to "subject", because however structured and inherited the condition of the individuals, their room for maneuver is still limited.

\section{FINAL CONSIDERATIONS}

The aim of this article was to analyze the career prospects of public high school students in a city in the interior of São Paulo with regard to social, family, educational and cultural aspects. A contribution of the article is that it brings to the discussion about career the theory of French sociologist, Pierre Bourdieu, who discusses the education system as reproducing social classes. Since the education system is an important element in the context of career theories and in the career development process, understanding such a system to be a reproducer of class is obviously a limitation with regard to those who may or may not have a career. It is these possible limitations that need to be discussed in the context of career studies, by making two aspects obvious: "careers for whom" and "who can have a career".

The research conducted with 3,247 high school students from public schools in a city in the interior of São Paulo showed that the processes of social class reproduction are quite evident and limit the career prospects of these students. To arrive at this conclusion, cluster and factorial analyses were conducted of the data that were collected from a structured questionnaire. Cluster analysis allowed six groups to be identified. These were labelled: Decided, Guided, Insecure, Stagnant, Undecided and Pessimists. Factor analysis made it possible to identify the capital (economic, social and cultural) that influences and limits the career prospects of the young interviewees.

The results reinforce Bourdieu's assertion that the education system is a major player in elements of the dominant classes, but is also evidence of some differences when these groups are correlated with the sociodemographic factors of the young participants in the research. The differences between the social classes are evident, showing that individuals from the lower classes have the prospect of adopting unsafe and stagnant behaviors with regard to what they do after leaving high school. Those young people, who come from families with a higher level income, represent those with behavioral prospects of decision and indecision regarding their choice of profession. The Decided want to leave high school and work. The Undecided want to work too, but they still do not know what they are going to do. Finally, those young people whose families have the highest levels of income of all those surveyed have both guided and pessimistic behavioral prospects. The Guided are likely to continue their studies and have no need to work when they leave high school. The Pessimists view free public high school in a negative way with regard to a possible professional placement in the market. 


\section{REFERENCES}

AKKERMANS, J. et al. It's all about career-skills: effectiveness of a career development intervention for young employees. Human Resource Management, v. 54, n. 4, p. 533-551, 2015.

ARTHUR, M. B. The boundaryless career: a new perspective for organizational inquiry. Journal of Organizational Behavior, v. 15, n. 4, p. 295-306, 1994.

ARTHUR, M. B.; HALL, D. T.; LAWRENCE, B. S. Generating new directions in career theory: The case for a transdisciplinary approach. Handbook of career theory, v. 7, p. 25, 1989.

ARTHUR, M. B.; KHAPOVA, S. N.; WILDEROM, C. P. M. Career success in a boundaryless career world. Journal of Organizational Behavior, v. 26 , n. 2, p. 177-202, 2005.

BONAMINO, A. et al. Os efeitos das diferentes formas de capital no desempenho escolar: um estudo à luz de Bourdieu e de Coleman. Revista Brasileira de Educação, v. 15, n. 45, p. 487-499, 2010.

BOURDIEU, P. A gênese dos conceitos de habitus e de campo. In: BOURDIEU, P. O poder simbólico. Rio de Janeiro: Bertrand-Brasil, 1989.

BOURDIEU, P. Questões de sociologia. Rio de Janeiro: Marco Zero, 1983.

BOURDIEU, P. The forms of capital. In: RICHARDSON, J. Handbook of theory and research for the sociology of education. Westport: Greenwood, 1986.

BOURDIEU, P. The practice of reflexive sociology. In: BOURDIEU, P.; WACQUANT, L. J. D. An invitation to reflexive sociology. Chicago: The University of Chicago Press, 1992.

BOURDIEU, P. The social conditions of the international circulation of ideas. Actes de la recherche en sciences sociales, n. 5, p. 3-8, 2002.

BOURDIEU, P.; PARESSON, J. C. A reprodução: elementos para uma teoria do sistema de ensino. Rio de Janeiro: Francisco Alves, 1975.

CONNOLLY, P.; HEALY, J. Symbolic violence, locality and social class: the educational and career aspirations of 10-11-year-old boys in Belfast. Pedagogy, Culture and Society, v. 12, n. 1, p. 15-33, 2004.

CLARK, B.; JOUBERT, C.; MAUREL, A. The career prospects of overeducated Americans. IZA Journal of Labor Economics, v. 6, n. 1, 2017.

DEFILLIPI, R.; ARTHUR, M. B. The boundaryless career: a competencybased perspective. Journal of Organizational Behavior, v. 15, n. 4, p. 307-24, 1994.

DENAULT, A. S. et al. Extracurricular activities and career indecision: A look at the mediating role of vocational exploration. Journal of Vocational Behavior, v. 110, p. 43-53, 2019.

GALE, T.; PARKER, S. Calculating student aspiration: Bourdieu, spatiality and the politics of recognition. Cambridge Journal of Education, v. 45, n. 1, p. 81-96, 2015.
HAIR, J. et al. Análise multivariada de dados. 6. ed. Porto Alegre: Bookman, 2009.

HALL, D. T. Careers in and out of organizations. New York: Sage, 2002.

HARRINGTON, B.; HALL, D. T. Career management \& work-life integration: using self-assessment to navigate contemporary careers. New York: Sage, 2007.

LEHMANN, W. Working-class students, habitus, and the development of student roles: a Canadian case study. British Journal of Sociology of Education, v. 33, n. 4, p. 527-546, 2012.

NEWMAN, B. K. Career change for those over 40: Critical issues and insights. The Career Development Quarterly, v. 44, n. 1, p. 64, 1995.

NOGUEIRA, C. M. M.; NOGUEIRA, M. A. A sociologia da educação de Pierre Bourdieu: limites e contribuições. Educação \& Sociedade, v. 23, n. 78, p. 15-35, 2002.

PEIPERL, M.; BARUCH, Y. Back to square zero: the post-corporate career. Organizational Dynamics, v. 25, n. 4, p. 7-22, 1997.

RIUTORT, P. Compêndio de sociologia. São Paulo: Paulus, 2008.

ROGNSTAD, M. K.; AASLAND, O.; GRANUM, V. How do nursing students regard their future career? Career preferences in the post-modern society. Nurse Education Today, v. 24, n. 7, p. 493500, 2004.

SUTIN, A. R. et al. Personality and career success: Concurrent and longitudinal relations. European Journal of Personality, v. 23, n. 2, p. 71-84, 2009.

THIRY-CHERQUES, H. Pierre Bourdieu: a teoria na prática. Revista de Administração Pública, v. 40, n. 1, p. 27-53, 2006.

THOMPSON, M. N. et al. Integrating job loss, unemployment, and reemployment with Social Cognitive Career Theory. Journal of Career Assessment, v. 25, n. 1, p. 40-57, 2017.

VALLE, I. R. O lugar da educação (escolar) na sociologia de Pierre Bourdieu. Revista Diálogo Educacional, v. 13, n. 38, p. 411-437, 2013.

VARGAS, M. L. F. Estudos sobre o funcionamento do sistema de ensino: da reprodução das desigualdades sociais ao efeito escola. Cadernos de Educação, v. 32, p. 105-122, 2009.

WRIGHT, S. L.; JENKINS-GUARNIERI, M. A.; MURDOCK, J. L. Career development among first-year college students: college self-efficacy, student persistence, and academic success. Journal of Career Development, v. 40, n. 4, p. 292-310, 2013.

ZELLWEGER, T.; SIEGER, P.; HALTER, F. Should I stay or should I go? Career choice intentions of students with family business background. Journal of Business Venturing, v. 26, n. 5, p. 521 536, 2011. 
Heliani Berlato

ORCID: https://orcid.org/0000-0003-2480-8293

Ph.D. in Business Administration from the Faculty of Economics, Administration and Accounting of the University of São Paulo (FEA/USP); Associate Professor at the "Luiz de Queiroz" School of Agriculture of the University of São Paulo (ESALQ/USP), Piracicaba - SP, Brazil. E-mail: hberlato@usp.br

\section{Luciano Mendes}

ORCID: https://orcid.org/0000-0002-6159-7184

Ph.D. in Administration from the Federal University of Rio Grande do Sul (UFRGS); Associate Professor at the "Luiz de Queiroz" School of Agriculture of the University of São Paulo (ESALQ/USP), Piracicaba - SP, Brazil. E-mail: mendes@usp.br

\section{Danilo Andretta}

ORCID: https://orcid.org/0000-0003-4139-6550

Master's degree in Administration from the "Luiz de Queiroz" School of Agriculture of the University of São Paulo (ESALQ/USP), Piracicaba - SP, Brazil. E-mail: danilo.andretta@usp.br 